\title{
Old lessons relearnt
}

\author{
Elizabeth Loder acting head of research
}

The BMJ

In medicine as in history we often have to learn things the hard way. Sometimes we don't recognise the value of something until it is gone. The 2012 Health and Social Care Act, for example, eliminated strategic health authorities in England. Our editorialists Nick Black and Nicholas Mays point out that only a few years later regional authority is being reintroduced, in the form of sustainability and transformation plans (doi:10.1136/ bmj.i6064). The lesson relearnt is that an intermediate level of governance is needed between local and national services. Meanwhile, the advice Black and Mays offer about this change could be given to Donald Trump's transition team too: "The government also needs to be realistic in its expectations of how long it will take to realise the profound changes envisaged."

Employee recognition schemes are standard in other businesses but not so common in healthcare. This puzzles the health minister Philip Dunne, who has been quoted as saying, "It seems extraordinary, it's absolutely standard practice across most other industries: people's achievement is recognised. We need to do more of that to raise the status, and self motivation of the staff" (http://bit.ly/2gdeInJ). He spoke in defence of the plan by England's health secretary, Jeremy Hunt, to boost GPs' morale through awards and the honours list. These good intentions attract scorn from Margaret McCartney (doi:10.1136/bmj.i5980), who observes, "The NHS is in meltdown, but the Empire strikes back."

Most people enjoy rewards, even small ones, and sometimes prizes do incentivise good behaviour. In medicine, though, the cultural narrative and social norms emphasise altruism. Doctors resent the implication that they would work harder, better, or more happily in the expectation of accolades or honours. They see this as a slur on their professionalism. They may be right. An almost incomprehensible but highly cited economics paper on "prosocial behaviour" says there is substantial evidence that rewards, "whether material or image-related," produce doubts about the reasons for good deeds. ${ }^{1}$ As the authors put it, "Good actions become suspected of being motivated by appearances, which limits the effectiveness of policies based on 'image rewards' such as public praise and shame." The old lesson here? It's tricky to apply business principles to medicine, which at its heart is a moral and not an economic enterprise.

Finally, how many times must we be reminded that criminalisation of non-medical use of drugs or other substances simply does not work? In the United States prohibition was a disaster, but that didn't stop the later declaration of the "war on drugs." This has been characterised more as a "war on public health" because of consequences such as violence, crime, discrimination, and lengthy prison sentences (doi:10.1136/bmj. i1742). Richard Hurley investigates why most professional medical societies "have little to say about policies such as the criminalisation of people who use drugs" (doi:10.1136/bmj. i6087). The $B M J$ is now on record in support of decriminalisation (doi:10.1136/bmj.i6067). Health should be the central goal of any drug policy, which must be underpinned by evidence. Here we can draw on many lessons learnt from earlier attempts to regulate prescription drugs, alcohol, and tobacco.

Even Donald Trump has said that he tries to learn from previous experience (http://bit.ly/2fUnvdN). Let's hope we all prove able to do that.

1 Benabou R, Tirole J. Incentives and prosocial behavior. https://www.princeton.edu/ $\sim$ rbenabou/papers/AER\%202006.pdf.

Published by the BMJ Publishing Group Limited. For permission to use (where not already granted under a licence) please go to http://group.bmj.com/group/rights-licensing/ permissions 